\title{
Phylogeny and morphologic evolution of the Ordovician Camerata (Class Crinoidea, Phylum Echinodermata)
}

\author{
Selina R. Cole \\ School of Earth Sciences, The Ohio State University, 275 Mendenhall Laboratory, 125 South Oval Mall, Columbus, OH 43210, USA \\ 〈cole.678@osu.edu〉
}

\begin{abstract}
The subclass Camerata (Crinoidea, Echinodermata) is a major group of Paleozoic crinoids that represents an early divergence in the evolutionary history and morphologic diversification of class Crinoidea, yet phylogenetic relationships among early camerates remain unresolved. This study conducted a series of quantitative phylogenetic analyses using parsimony methods to infer relationships of all well-preserved Ordovician camerate genera (52 taxa), establish the branching sequence of early camerates, and test the monophyly of traditionally recognized higher taxa, including orders Monobathrida and Diplobathrida. The first phylogenetic analysis identified a suitable outroup for rooting the Ordovician camerate tree and assessed affinities of the atypical dicyclic family Reteocrinidae. The second analysis inferred the phylogeny of all well-preserved Ordovician camerate genera. Inferred phylogenies confirm: (1) the Tremadocian genera Cnemecrinus and Eknomocrinus are sister to the Camerata; (2) as historically defined, orders Monobathrida and Diplobathrida do not represent monophyletic groups; (3) with minimal revision, Monobathrida and Diplobathrida can be re-diagnosed to represent monophyletic clades; (4) family Reteocrinidae is more closely related to camerates than to other crinoid groups currently recognized at the subclass level; and (5) several genera in subclass Camerata represent stem taxa that cannot be classified as either true monobathrids or true diplobathrids. The clade containing Monobathrida and Diplobathrida, as recognized herein, is termed Eucamerata to distinguish its constituent taxa from more basally positioned taxa, termed stem eucamerates. The results of this study provide a phylogenetic framework for revising camerate classification, elucidating patterns of morphologic evolution, and informing outgroup selection for future phylogenetic analyses of post-Ordovician camerates.
\end{abstract}

\section{Introduction}

Subclass Camerata Wachsmuth and Springer, 1885 is a major clade of Paleozoic crinoids comprising nearly 350 genera, including some of the earliest known crinoid taxa (Guensburg and Sprinkle, 2003). Camerates persisted from the Early Ordovician (Tremadocian) to the late Permian (Lopingian) and were ecologically significant constituents of lower and middle Paleozoic crinoid evolutionary faunas (CEF) (Ausich and Deline, 2012). Recent quantitative phylogenetic analysis of Early-Middle Ordovician crinoids indicates camerates form a monophyletic group and were the earliest clade to diverge within the Crinoidea (Ausich et al., 2015), making the Camerata the sister group to all other crinoids. Because of their ecological significance, taxonomic diversity, and early divergence from other crinoid clades, understanding the early evolutionary relationships among camerate lineages is important for interpreting patterns of morphologic evolution at the base of the crinoid tree of life during initial diversification of the class. Phylogenetic relationships within the Camerata remain obscure, however, and the monophyly of higher camerate taxa remains untested.

Camerates are united by the presence of rigidly ankylosed thecal and tegminal plates, fixed brachials and interbrachials incorporated into the calyx, subtegminal mouth, and typically additional plates in the posterior interray (Ubaghs, 1978).
The subclass has traditionally been divided into order Diplobathrida, which is characterized by two circlets of plates (basals and infrabasals) below the radial circlet, and order Monobathrida, which possesses only one circlet of plates (basals) below the radial circlet (Moore and Laudon, 1943a). Although the known stratigraphic range of both orders begins in the Lower Ordovician (Tremadocian), diplobathrids went extinct at the end Mississippian (Serpukhovian) whereas monobathrids persisted until the end Permian (Lopingian). Diplobathrids are the less taxonomically diverse of the two orders, comprising roughly a third of the total generic diversity of camerates. During the Ordovician, however, diplobathrids exceeded monobathrids as constituents of the early Paleozoic CEF and in terms of taxonomic diversity, with nearly twice as many genera as the Monobathrida (Ausich and Deline, 2012). Following the end-Ordovician extinction, monobathrids replaced diplobathrids as the dominant camerate constituents of the middle Paleozoic CEF (Eckert, 1988; Ausich et al., 1994).

Although some general patterns of camerate evolutionary history have been established, the absence of a phylogeny for the Camerata has restricted investigation of both systematic and macroevolutionary questions within the clade. Many recent studies have highlighted that phylogeny provides the valuable context of shared evolutionary history (Carlson, 2001; Kelley et al., 2013). To this end, a phylogenetic analysis was conducted 
that considered all currently recognized Ordovician camerate genera to explore evolutionary relationships within the Camerata, assess the monophyly of higher camerate taxa, and evaluate the congruence of the traditional classification scheme with phylogeny. This is the first quantitative phylogenetic study to focus specifically on the Ordovician Camerata. As a result, it provides insight into a significant period in camerate evolutionary history and elucidates evolutionary relationships and patterns of morphologic evolution at the base of the crinoid tree of life. In addition to informing systematic revision of the group, the recovered trees provide a phylogenetic framework for the study of macroevolutionary patterns within the subclass Camerata.

\section{Previous work on camerate phylogeny}

The relationship of camerates to other major crinoid groups has, until recently, remained uncertain. Systematists responsible for establishing camerate classification made little attempt to infer the relationship of camerates to other crinoid groups (Moore, 1952; Moore and Laudon, 1943a; Ubaghs, 1978). Since then, a number of studies have considered the relationships among the major crinoid groups, including the Camerata, on the basis of either quantitative phylogenetic analyses or qualitative study of cladograms. The major hypotheses that have been proposed for camerates are summarized by Cole and Ausich (2015, fig. 1) and include past suggestions that they are most closely related to disparids (Simms, 1993) or cladids (Ausich, 1998a, 1998b) or are sister to a clade comprised of disparids and cladids (Guensburg, 2012). The most recent and comprehensive quantitative analysis, which considered Early-Middle Ordovician crinoid taxa, concluded that the Camerata: (1) form a monophyletic group, and (2) were the first clade to diverge from the rest of the Crinoidea (Ausich et al., 2015). It should be noted that the first point, the monophyly of the Camerata, has been supported by previous phylogenetic analyses by Ausich (1998a, 1998b) for all camerate taxa included and by Guensburg (2012) with the exception of Eknomocrinus Guensburg and Sprinkle, 2003.

Although the relationship of camerates to other crinoid clades has now been established, few quantitative phylogenetic analyses have been conducted at lower taxonomic levels, and as a result, evolutionary relationships at the taxonomic rank of order and below remain poorly understood. The monophyly of orders Diplobathrida and Monobathrida have been implicitly assumed yet have never been substantiated through quantitative testing. Qualitative familylevel cladograms have represented the monobathrid-diplobathrid relationship as a simple basal divergence (Moore, 1952) or left the relationship between orders largely ambiguous (Ubaghs, 1978; Simms, 1993; Cole and Ausich, 2015, fig. 2). In the most comprehensive phylogeny of Ordovician camerates, which considered Arenig to Caradoc taxa, all monobathrids and most diplobathrids were left unresolved on a polytomy, and thus the monophyly of the orders could not be established (Ausich, 1998b).

Our poor understanding of evolutionary relationships within the Camerata, which has been repeatedly acknowledged (Ubaghs, 1978; Simms, 1993), is reflected in the classification of subordinal taxa. For example, the diplobathrid suborder Zygodiplobathrina (Ubaghs, 1953, 1978) is thought to represent a polyphyletic grouping although its status as a clade has never been tested through phylogenetic analysis. Similarly, the phylogenetic reality of superfamilies Dimerocrinitacea and Rhodocrinitacea have been questioned (Brower, 1973; Frest and Strimple, 1981), and revisions of many camerate families to better reflect phylogeny have been proposed (Brower and Veinus, 1974; Kolata, 1982; Ausich, 1985, 1986; Rhenberg et al., 2015). These long-suspected systematic issues highlight the need for comprehensive camerate phylogenies to inform systematic revision and amend non-monophyletic groups.

\section{Preliminary analysis and outgroup selection}

Rooting the camerate tree.-Before inferring the phylogeny of Ordovician camerates, a preliminary analysis with two primary objectives was conducted. The first goal of this preliminary analysis was to identify a suitable outgroup for the camerate phylogeny. Outgroup selection is important in phylogenetic analysis for rooting the tree and determining character polarity, which in turn may affect branching order, inferred relationships, and interpretations of morphological change within the ingroup. Using distant outgroups can result in an incorrect topology that is spuriously rooted on a long branch, and thus, the outgroup(s) selected should ideally be as closely related to the ingroup as possible to break up long branches and differentiate ancestral states from derived character states (Wheeler, 1990; Smith et al., 1992; Smith, 1994a, 1994b).

Rooting the crinoid tree of life has proven one of the most challenging aspects of inferring phylogeny of the clade. This is due in part to its rapid early radiation and long-uncertain evolutionary origins, both of which complicate rooting phylogenies (Shavit et al., 2007; Smith and Zamora, 2009). The first appearance of crinoids in the fossil record (Lower Ordovician, Tremadocian) is marked by the occurrence of representatives from several major groups, including camerates, protocrinoids, cladids, and disparids. This diversity of crinoid taxa at their first appearance precludes rooting the tree with a single crinoid taxon based on stratigraphic appearance alone. Because Camerata was the earliest recognized clade to diverge from the rest of Crinoidea, it is similarly plagued by this issue of outgroup selection (Ausich et al., 2015).

Recent phylogenetic analyses of pelmatozoans have suggested crinoids are nested within blastozoan clades such as diploporoids, eocrinoids, and glyptocystitoids (Sumrall, 2014, 2015). This relationship has been further corroborated by organic molecules recovered from fossil echinoderms (O'Malley et al., 2016). Because the potential sister group to crinoids is nested within the Blastozoa, representatives from these clades have been successfully utilized as outgroups for analyses of early crinoids (Ausich, 1998a, 1998b; Ausich et al., 2015). For this study, however, the paucity of unequivocally homologous characters shared between blastozoan outgroups and camerate crinoids makes it difficult to determine character polarization with certainty and avoid spurious rooting of the ingroup. Consequently, it was deemed advantageous to conduct a preliminary analysis of early camerates and other representative clades to identify an outgroup taxon that is more closely related to the camerate ingroup.

Affinities of family Reteocrinidae.-The second goal of the preliminary analysis was to identify the phylogenetic position of 
the family Reteocrinidae Wachsmuth and Springer, 1885 relative to Camerata. The genera Reteocrinus Billings, 1859, Gaurocrinus Miller, 1883, Cnemecrinus Guensburg and Sprinkle, 2003, and Quechuacrinus Guensburg and Waisfeld, 2015 are currently assigned to Reteocrinidae, which has traditionally been considered a family of diplobathrid camerates. The Reteocrinidae, however, lack some of the typical camerate characters and possess others that are idiosyncratic. Morphological traits that are atypical for most Ordovician camerates but variably possessed by reteocrinids include apinnulation, irregularly plated interrays that are not ankylosed, pentameric stems, and more than two fixed primibrachials (Table 1). Similarities have been noted between Reteocrinus and both the cladid Dendrocrinus Hall, 1852 and the disparid Iocrinus Hall, 1866 (Moore and Laudon, 1943a). On the basis of these characters, it has been suggested that reteocrinids do not belong within Camerata (Kelly, 1986; Donovan and Cope, 1989), although this proposal has not been tested quantitatively. Two of the reteocrinid genera, Cnemecrinus and Quechuacrinus, are Early Ordovician in age, making them taxa of interest for the outgroup selection analysis of early camerates. Fortuitously, the preliminary phylogenetic analysis conducted for outgroup selection also offers the opportunity to address this secondary question-affinity of family Reteocrinidae — with a single analysis.

Preliminary analysis.-The preliminary phylogenetic analysis included twenty-six genera sampled from early blastozoans (six genera), cladids (four genera), protocrinoids (two genera), monobathrid camerates (five genera), non-reteocrinid diplobathrid camerates (six genera), and reteocrinids (three genera; Table 2). Taxa were coded for the preliminary analysis following the same methods used for the comprehensive analysis (see the following). The characters and character states used for the preliminary analysis were identical to those used for the comprehensive analysis, with the exception of five additional characters that were coded to encompass morphological variation of the additional taxonomic groups sampled (Supplemental Data 1). Of the 117 characters coded in total, 90 proved parsimony-informative. The six blastozoan taxa were designated as the outgroups for the analysis. A parsimony analysis was conducted in PAUP* v. 4.0a147 (Swofford, 2003) using a heuristic search with 1,000 random addition sequence replicates with tree bisection reconnection (TBR), holding 10 trees at each step and collapsing all branches with a maximum branch length of zero. Values for the consistency index $(\mathrm{CI})$ and retention index (RI) were recorded for the recovered trees, and bootstrap values and Bremer support were calculated using PAUP*.
Results and discussion.-Twelve most parsimonious trees were recovered from the phylogenetic analysis with a tree length of 360 steps each and CI and RI values of 0.528 and 0.592 , respectively. The strict consensus of these trees is well resolved with only small local polytomies (Fig. 1). Three monophyletic groups form that are respectively comprised of the four cladid genera, the two protocrinoid genera, and all genera traditionally considered camerates, including Cnemecrinus, Eknomocrinus, Reteocrinus, Quechuacrinus, and all other included monobathrids and diplobathrids. Although the order of branching relationships of these clades differs somewhat from the topology of Ausich et al. (2015), the tree recovers the fundamental basal split between camerate and non-camerate crinoids. Within the camerate clade, Eknomocrinus and Cnemecrinus are the first to diverge, forming a clade that is well-supported by bootstrap and Bremer support values. Two reteocrinids, Reteocrinus and Quechuacrinus, form another well-supported clade. The remaining camerate taxa are not clearly divided into monobathrid and diplobathrid groups. Based on the low taxonomic sampling of camerates in this analysis and low support values for most nodes within the camerate clade, interpretations of relationships among Ordovician camerates should be made based on the subsequent analysis (see below) rather than on this preliminary analysis.

Results indicate: (1) members of family Reteocrinidae are more closely related to camerate crinoids than to protocrinoids or cladids and thus should maintain status as camerate taxa, and (2) Eknomocrinus and Cnemecrinus form the sister group to the rest of Camerata and thus are the most suitable taxa for rooting the camerate tree.

\section{Materials and methods}

Taxon sampling and data collection.-The comprehensive analysis considered all currently named Ordovician camerate genera, which includes 38 diplobathrids and 17 monobathrids (Table 3). At the outset of the study, the monobathrids Schizocrinus Hall, 1847 and Habrotecrinus Guensburg and Sprinkle, 2003 were excluded due to poor preservation $(<50 \%$ of characters preserved), and the incertae sedis monobathrid (?) Delgadocrinus Ausich, Sá, and Gutiérrez-Marco, 2007 was excluded due to its uncertain assignment to the Camerata. Thus, 52 genera in total, 38 diplobathrids and 14 monobathrids, were included in the analysis. A representative species was selected for each genus and coded using museum specimens available at the Smithsonian National Museum of Natural History, the London Natural History Museum, the Chicago Field Museum,

Table 1. Morphological features of genera in family Reteocrinidae. Character states of the typical camerate condition are marked with a ' 0 '; character states of the 'reteocrinid' condition are marked with a ' 1 .' Character states are as follows: Pinnulation: $0=$ pinnulate, $1=$ apinnulate; Interray plating: $0=$ regular, $1=$ irregular; Interray suturing: $0=$ ankylosed, $1=$ flexible; Stem: $0=$ holomeric, $1=$ pentameric; Primibrachials: $0=2,1=$ greater than or equal to three. Ordovician camerates sharing reteocrinid-like features are listed.

\begin{tabular}{lllll}
\hline Taxa & Pinnulation & Interray plating & Interray suturing & Stem \\
\hline Reteocrinus & 1 & 1 & 1 & 1 \\
Quechuacrinus & 1 & 1 & 1 & 1 \\
Cnemecrinus & 1 & 0 & 0 & 1 \\
Gaurocrinus & 0 & 1 & 1 & 0 \\
Other Ordovician camerates with & Eknomocrinus & Canistrocrinus & Xenocrinus & 0 \\
$\quad$ 'reteocrinid' (state 1) condition & Adelphicrinus & Adelphicrinus & & Bromidocrinus \\
& & & Cotylacrinna \\
& & & Eknomocrinus \\
& & Adelphicrinus & Adelphicrinus \\
& & & \\
& & & \\
\end{tabular}


Table 2. Genera, species, and coding references used in the preliminary phylogenetic analysis. Asterisk $(*)$ denotes non-type species coded due to poor preservation of the type. First appearance is given for genus.

\begin{tabular}{|c|c|c|}
\hline Genus and species coded & First appearance & Coding references \\
\hline $\begin{array}{l}\text { Blastozoa } \\
\text { Cheirocystis fultonensis* Sumrall and Schumacher, } 2002 \\
\text { Echinosphaerites aurantium (Gyllenhaal, 1772) } \\
\text { Eumorphocystis multiporata Branson and Peck, } 1940 \\
\text { Glyptocystella loeblichi (Bassler, 1943) } \\
\text { Protocrinites rugatus* Bockelie, } 1984 \\
\text { Rhopalocystis destombesi Ubaghs, } 1963\end{array}$ & $\begin{array}{l}\text { Katian } \\
\text { Katian } \\
\text { Sandbian } \\
\text { Sandbian } \\
\text { Sandbian } \\
\text { Ordovician }\end{array}$ & $\begin{array}{l}\text { Sumrall and Schumacher, } 2002 \\
\text { Bockelie, 1981, } 1984 \\
\text { Branson and Peck, } 1940 \\
\text { Sprinkle, 1982a } \\
\text { Bockelie, } 1984 \\
\text { Ubaghs, } 1963\end{array}$ \\
\hline $\begin{array}{l}\text { Cladida } \\
\text { Aethocrinus moorei Ubaghs, } 1969 \\
\text { Apektocrinus ubaghsi Guensburg and Sprinkle, } 2009 \\
\text { Compagicrinus fenestratus Jobson and Paul, } 1979 \\
\text { Elpasocrinus radiatus Sprinkle and Wahlman, } 1994\end{array}$ & $\begin{array}{l}\text { Tremadocian } \\
\text { Tremadocian } \\
\text { Floian } \\
\text { Floian }\end{array}$ & $\begin{array}{l}\text { Ubaghs, 1969; Rozhnov, } 1988 \\
\text { Guensburg and Sprinkle, } 2009 \\
\text { Rozhnov, 1988; Webster and Maples, } 2006 \\
\text { Sprinkle and Wahlman, } 1994\end{array}$ \\
\hline $\begin{array}{l}\text { Camerata, Diplobathrida } \\
\text { Archaeocrinus microbasalis* (Billings, 1857) } \\
\text { Cnemecrinus fillmorensis Guensburg and Sprinkle, } 2003 \\
\text { Euptychocrinus skopaios* Brower, 1994 } \\
\text { Neoarchaeocrinus pyriformis (Billings, 1857) } \\
\text { Proexenocrinus inyoensis Strimple and McGinnis, } 1972 \\
\text { Quechuacrinus tisca Guensburg and Waisfeld, 2015 } \\
\text { Reteocrinus alveolatus* (Miller and Gurley, 1894) } \\
\text { Rhaphanocrinus subnodosus (Walcott, 1883) } \\
\text { Trichinocrinus terranovicus Moore and Laudon, 1943b }\end{array}$ & $\begin{array}{l}\text { Darriwilian } \\
\text { Tremadocian } \\
\text { Katian } \\
\text { Darriwilian } \\
\text { Floian } \\
\text { Floian } \\
\text { Sandbian } \\
\text { Darriwilian } \\
\text { Darriwilian }\end{array}$ & $\begin{array}{l}\text { Wachsmuth and Springer, } 1897 \\
\text { Guensburg and Sprinkle, } 2003 \\
\text { Brower, } 1994 \\
\text { Billings, 1859; Wachsmuth and Springer, } 1897 \\
\text { Strimple and McGinnis, 1972; Ausich, } 1985 \\
\text { Guensburg and Waisfeld, 2015 } \\
\text { Springer, 1911; Guensburg, } 1984 \\
\text { Wachsmuth and Springer, 1897 } \\
\text { Moore and Laudon, 1943b; Ausich, Bolton, and Cummings, } 1998\end{array}$ \\
\hline $\begin{array}{l}\text { Camerata, Monobathrida } \\
\text { Abludoglyptocrinus charltoni (Kolata, 1975) } \\
\text { Celtocrinus ubaghsi Donovan and Cope, } 1989 \\
\text { Eknomocrinus wahwahensis Guensburg and Sprinkle, } 2003 \\
\text { Glyptocrinus decadactylus Hall, } 1847 \\
\text { Xenocrinus baeri* (Meek, 1872) }\end{array}$ & $\begin{array}{l}\text { Sandbian } \\
\text { Floian } \\
\text { Tremadocian } \\
\text { Sandbian } \\
\text { Katian }\end{array}$ & $\begin{array}{l}\text { Kolata, } 1975 \\
\text { Donovan and Cope, } 1989 \\
\text { Guensburg and Sprinkle, } 2003 \\
\text { Wachsmuth and Springer, } 1897 \\
\text { Wachsmuth and Springer, 1897; Brower, } 1974\end{array}$ \\
\hline $\begin{array}{l}\text { Protocrinoidea } \\
\text { Glenocrinus globularis Guensburg and Sprinkle, } 2003 \\
\text { Titanocrinus sumralli Guensburg and Sprinkle, } 2003\end{array}$ & $\begin{array}{l}\text { Tremadocian } \\
\text { Tremadocian }\end{array}$ & $\begin{array}{l}\text { Guensburg and Sprinkle, } 2003 \\
\text { Guensburg and Sprinkle, } 2003\end{array}$ \\
\hline
\end{tabular}

and the Birmingham Lapworth Museum. Coding of specimens was supplemented using primary taxonomic literature (Table 3). In instances where museum specimens were inaccessible, taxa were coded using primary taxonomic literature. For each genus, the species selected for coding was typically the type species except in cases where a non-type species preserved more characters than the type or where the type species was postOrdovician in age. Species were coded for 112 discrete characters, 64 binary and 48 multistate, that were selected to capture morphological variation among Ordovician camerates and are inferred to represent homologous structures among sampled taxa (Foote, 1994, 1999; Ausich, 1996; Kammer et al., 2013; Wright, 2015) (Supplemental Data 2). Of the characters coded, 85 proved to be parsimony-informative. The Tremadocian diplobathrid Eknomocrinus was designated as the outgroup based on the results of the preliminary analysis that identified Cnemecrinus and Eknomocrinus as sister to the Crinoidea. Although both taxa are Tremadocian in age, Eknomocrinus is from a lower stratigraphic horizon than Cnemecrinus (Guensburg and Sprinkle, 2003). Designation of Cnemecrinus instead of Eknomocrinus as the outgroup, however, resulted in only trivial changes in ingroup topology.

Phylogenetic analysis.-To assess evolutionary relationships among the Ordovician Camerata, a parsimony analysis was conducted in PAUP* v. 4.0 a147 (Swofford, 2003) using a heuristic search with 1,000 random addition sequences. TBR was used for the branch-swapping algorithm with no reconnection limit, and branches with a maximum length of zero were collapsed. All characters were left unordered and equally weighted. The parsimony analysis recovered 801 most parsimonious trees with lengths of 634 steps per tree. Strict consensus of the 801 most parsimonious trees resulted in a tree topology with little resolution (Supplemental Data 3). Subsequently, the characters were reweighted using the rescaled consistency (RC) function in PAUP*. This method of reweighting adjusts the weight of characters in an attempt to minimize homoplasy in the analysis (Farris, 1989; Smith, 1994b). After reweighting using RC, the analysis was run for 1,000 random addition sequences using the same search parameters as the initial search, and a single most parsimonious tree was recovered (Fig. 2). For the reweighted analysis, CI and RI values were recorded for the recovered tree, and bootstrap values and Bremer support were calculated using PAUP*

Additional analyses.-Additional character analyses were conducted in Mesquite (Maddison and Maddison, 2015) for the single most parsimonious tree recovered from the reweighted analysis (Fig. 2). Using the R package STRAP (Bell and Lloyd, 2015), the most parsimonious tree was plotted against the observed stratigraphic ranges of sampled genera to produce a time-scaled phylogeny (Fig. 3). Stratigraphic ranges of genera used to time-scale the tree were tabulated from Webster (2003) and updated to include new taxa and match current divisions of the International Chronostratigraphic Chart.

Stratigraphic congruence metrics were also calculated for the tree using STRAP to assess the fit of the recovered tree to observed stratigraphic ranges. The stratigraphic congruence measures used were the stratigraphic consistency index (SCI; Huelsenbeck, 1994), relative completeness index (RCI; Benton and Storrs, 1994), the gap excess ratio (GER; Willis, 1999), and Manhattan stratigraphic measure* (MSM*; Siddall, 1998; Pol and Norell, 2001). For each measure, the calculated value was compared to a null model of 1,000 trees generated through 


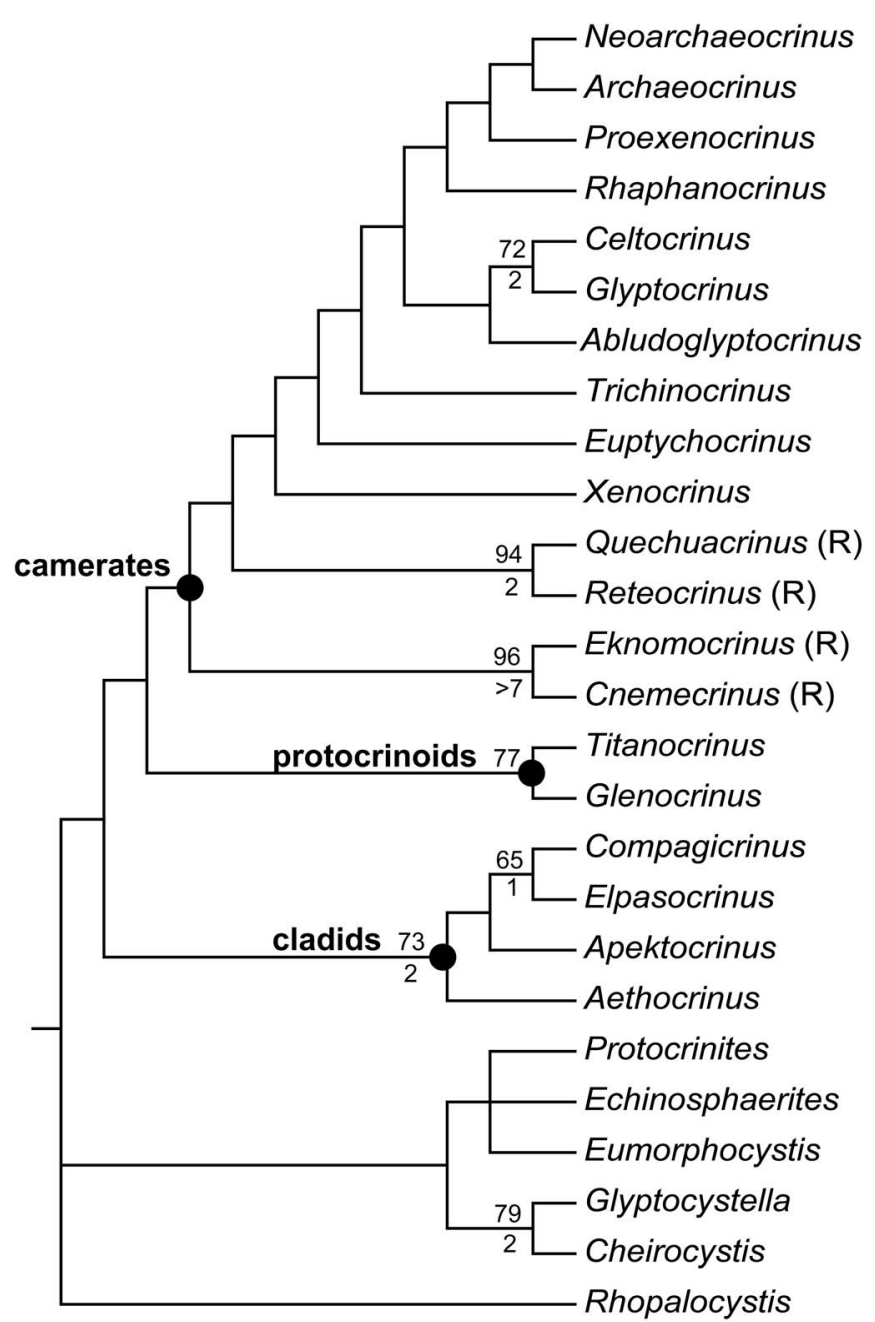

Figure 1. Strict consensus of 12 most parsimonious trees recovered from the preliminary phylogenetic analysis. Support for nodes is given by bootstrap values (above) and Bremer support (below). Labels at nodes are given for major clades; $(\mathrm{R})=$ taxa traditionally placed in family Reteocrinidae.

Monte Carlo simulation (Fig. 4), and a p-value was calculated for each of the observed metrics (Table 4).

Finally, to assess the relative completeness of taxon sampling in this analysis relative to the crinoid fossil record, preservation probability and sampling rate were calculated for Ordovician camerates using methods outlined by Foote (1997). This approach uses the distribution of taxonomic ranges to infer maximum likelihood estimates of per-interval sampling probability, thereby minimizing potential bias of finite sample size (Foote and Raup, 1996). All Ordovician camerate genera except Schizocrinus, Delgadocrinus, and Habrotecrinus were included in this analysis. Discrete time intervals were used based on stratigraphic ranges of genera tabulated from Webster (2003) updated to match current divisions of the International Chronostratigraphic Chart.

\section{Results}

Phylogenetic and other analyses.-The initial equally weighted parsimony analysis recovered 801 most parsimonious trees of 634 steps in length. The topology resulting from the strict consensus of these trees was largely unresolved with only two clades of two taxa (Anthracocrinus, Strimple and Watkins, 1955 and Gustabilicrinus Guensburg, 1984; Ptychocrinus Wachsmuth and Springer, 1885 and Euptychocrinus Brower, 1994) and one clade of three taxa (Atactocrinus Weller, 1916, Maquoketocrinus Slocom, 1924, and Ortsaecrinus Gil et al., 1999) resolved (Supplemental Data 3).

The subsequent reweighted analysis, which used RC to reweight characters based on the trees recovered in the initial analysis, produced a single most parsimonious tree (Fig. 2) with a length of 70.152 and CI and RI values of 0.319 and 0.507 , respectively. The four stratigraphic congruence metrics calculated for the recovered tree all proved significant, indicating the fit of the recovered tree to stratigraphy based on the observed stratigraphic ranges of taxa was significantly higher than for randomly generated trees (Table 4).

The per-interval preservation probability of camerate taxa was estimated to be 0.51 , and the per-lineage-million-year sampling rate was calculated to be 0.12 . The estimated sampling probability of Ordovician camerates is comparable to that of previous estimates for crinoids. For example, Foote and Raup (1996) calculated a per-interval preservation probability of 0.5 (equivalent to a sampling rate of 0.1 ) for 395 globally distributed Ordovician-Devonian crinoid genera that included both camerates and non-camerates (see Bapst and Hopkins, 2016). These estimates suggest the record is more than $70 \%$ complete at the genus level (Foote and Raup, 1996). Thus, the taxon sampling employed within this study is interpreted herein as a highly representative sample of the crinoid fossil record.

Tree topology and clades recognized.-For the reweighted parsimony analysis, the following results are presented in terms of the clades recovered, their relative placement within the tree, and diagnostic characters shared by taxa composing those clades. The major clades recovered are designated by letters at nodes in Figure 2. For each clade, unique combinations of traits are given that are diagnostic of their constituent taxa. It should be emphasized that these character combinations are comprised of both plesiomorphic and shared derived traits but are useful for diagnosing the taxa descended from each node. Characters in these combinations that represent synapomorphies (shared derived characters) are noted.

Two major clades were recovered that broadly correspond to the orders Monobathrida and Diplobathrida, with several exceptions. All diplobathrid genera form a single clade except for Rosfacrinus Le Menn and Spjeldnaes, 1996 and the four genera assigned to family Reteocrinidae (Reteocrinus, Quechuacrinus, Gaurocrinus, and Cnemecrinus). This diplobathrid clade is represented in Figure 2 by Node $\mathrm{G}$ and all of its descendents. All monobathrid genera form a single clade with the exception of Adelphicrinus Guensburg and Sprinkle, 2003 and Eknomocrinus. This monobathrid clade is represented in Figure 2 by Node D and all of its descendents. Most of the genera that do not fall within the monobathrid or diplobathrid clades are positioned near the base of the tree as taxa that are stem to the monobathrid and diplobathrid clades. These include Cnemecrinus, Eknomocrinus, Adelphicrinus, Reteocrinus, and Quechuacrinus. With Eknomocrinus designated as the outgroup, Adelphicrinus and Cnemecrinus are, respectively, the most basal lineages. If Cnemecrinus is designated as the outgroup, a clade composed of Adelphicrinus and Eknomocrinus is 
Table 3. Genera, species, and coding references used in the comprehensive phylogenetic analysis. Asterisk $(*)$ denotes non-type species coded due to poor preservation of the type; dagger $(\dagger)$ denotes non-type genus coded because type is Silurian. First appearance is given for genus. Family designation is based on traditional classification.

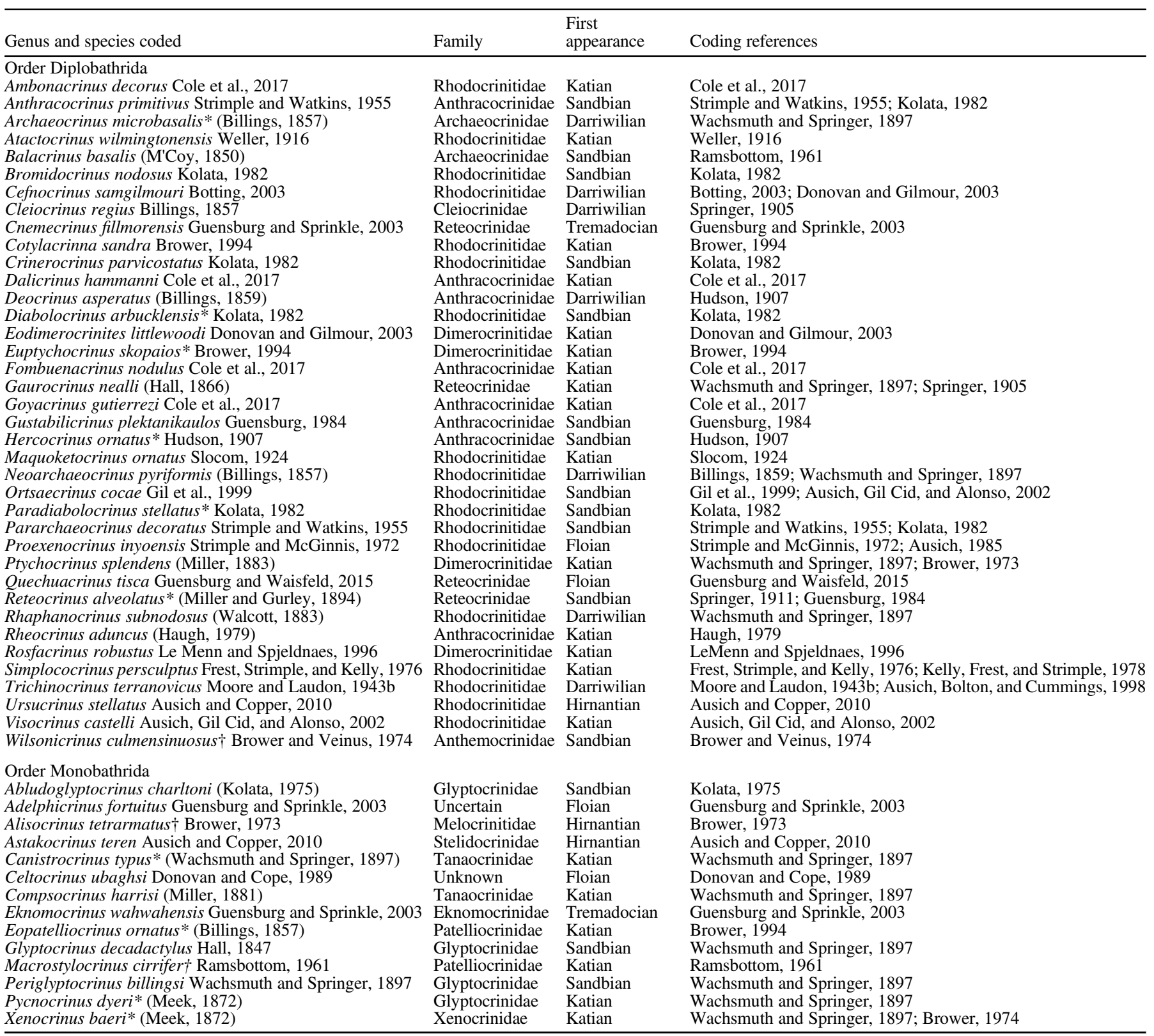




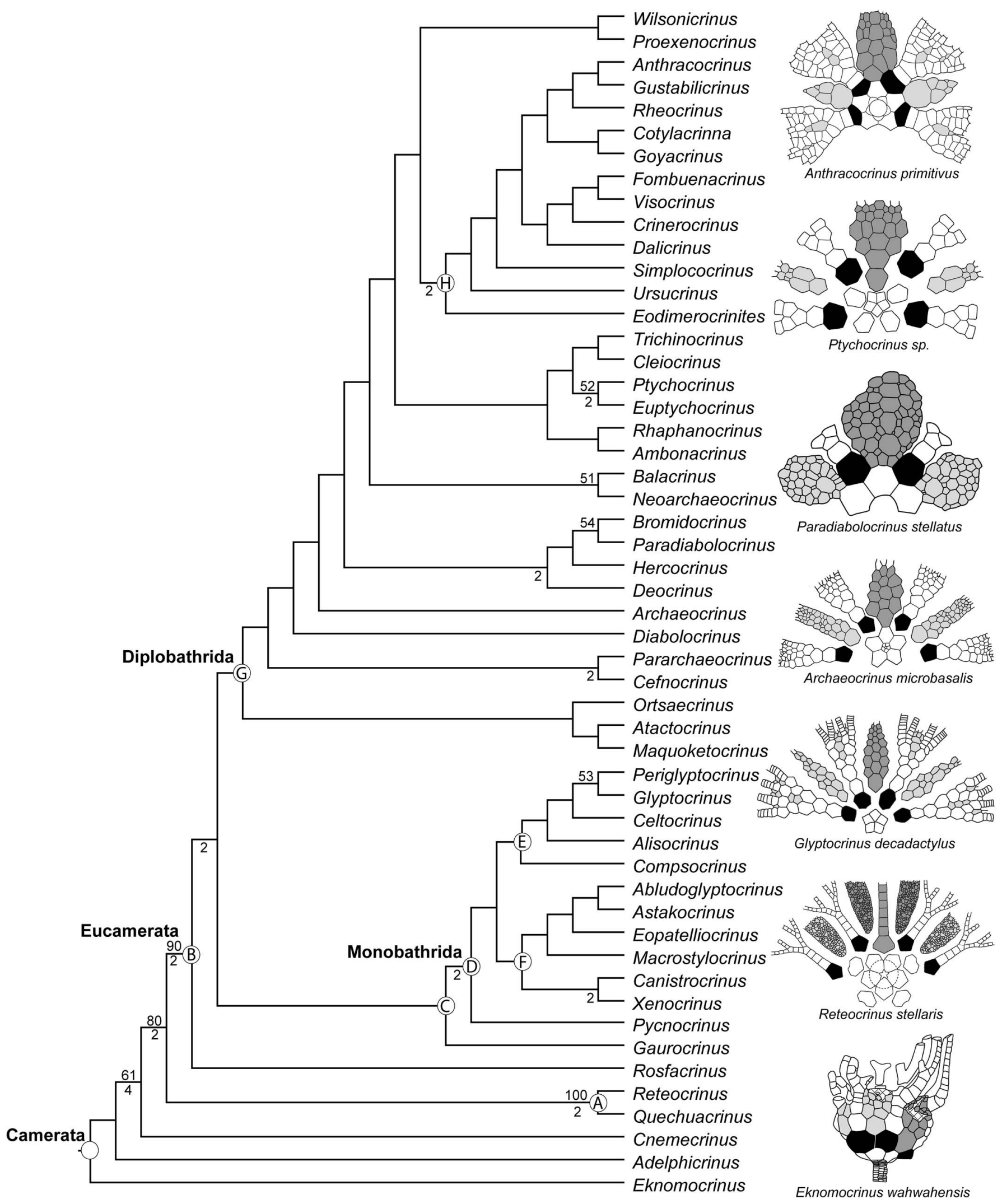




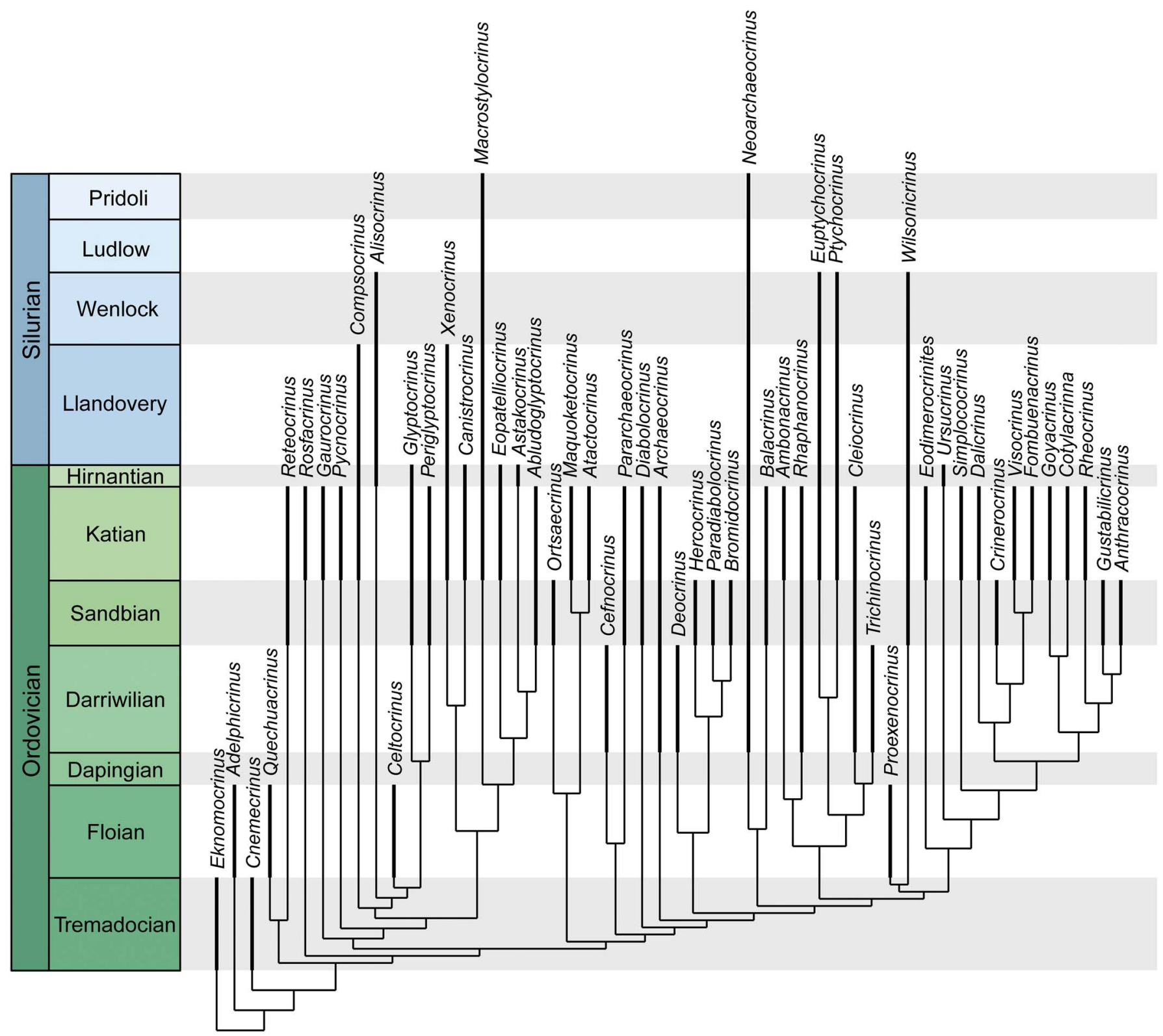

Figure 3. Time-scaled phylogeny from the single most parsimonious tree resulting from the comprehensive phylogenetic analysis. Genera with ranges extending beyond the Silurian (Neoarchaeocrinus, Givetian; Macrostylocrinus, Lochkovian) have been truncated.

most basal within the tree; topology of all other ingroup taxa is identical regardless of which of the two genera is used as the outgroup (Supplemental Data 4).

Moving tipward, the two stem taxa Reteocrinus and Quechuacrinus form a well-supported clade that is diagnosed by a number of traits, including: (1) interrays comprised of small, irregular plates, (2) interray plates not ankylosed, (3) posterior interrays with anitaxis plating, (4) posterior interrays with anitaxial ridge, (5) variable location of primaxil (3rd-5th primibrachial), (6) 20 free arm openings, (7) apinnulation, (8) rectilinear uniserial brachials, and (9) pentameric stems (Fig. 2, Node A). Trait (2) is a synapomorphy, whereas all others represent plesiomorphic traits. Rosfacrinus is basally positioned relative to the division of the monobathrid and diplobathrid clades. The node that includes Rosfacrinus, the monobathrid clade, and the diplobathrid clade is well-supported by both bootstrap values and Bremer support, and taxa in this clade share the following diagnostic traits: (1) primaxil located on the 2nd primibrachial, (2) pinnulation, (3) typically regular interray plating, and (4) non-pentameric stems (Fig. 2, Node B). Characters (1) and (2) are synapomorphies, whereas (3) and (4) are plesiomorphic traits.

The monobathrid clade as recognized herein comprises 12 Ordovician taxa. The dicyclic genus Gaurocrinus plots as sister to Monobathrida and shares several diagnostic traits with the clade, including: (1) radials are largest plates in calyx, (2) calyx high to very high, (3) anitaxis plating in the posterior interray, and (4) anitaxial ridge in the posterior interray. Traits (1) and (4) are synapomorphies (Fig. 2, Node C). Diagnostic traits shared by the monobathrid clade are: (1) one circlet of plates below the radial circlet, (2) basal circlet upright, and (3) radial circlet uninterrupted or only interrupted in the posterior interray. Traits (1) and (3) are 

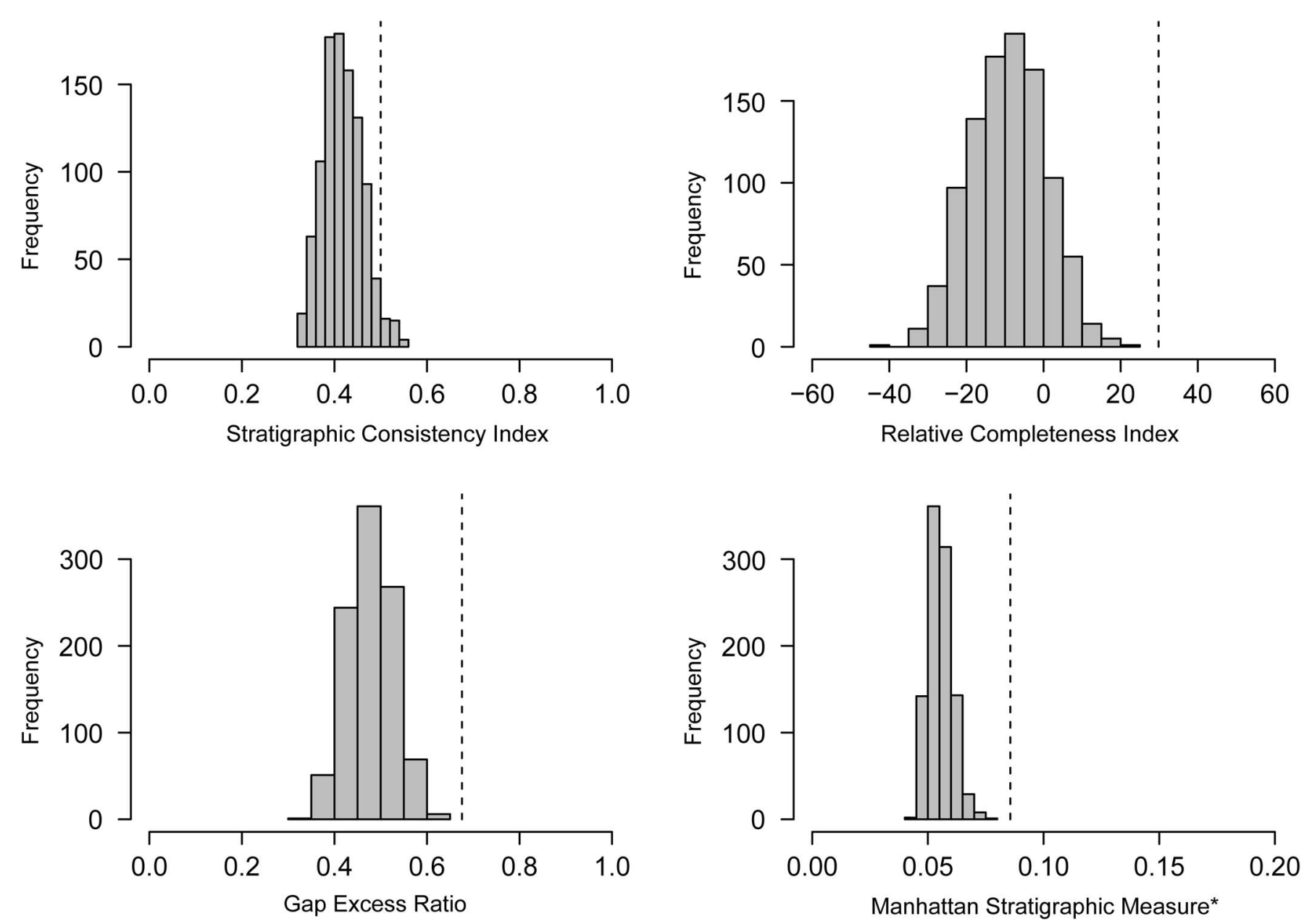

Figure 4. Stratigraphic congruence metrics for the recovered single most parsimonious tree. For each measure, the observed value (dashed line) is compared to a null distribution produced using a Monte Carlo simulation of 1,000 trees.

Table 4. Stratigraphic congruence metrics for the single most parsimonious tree resulting from the reweighted phylogenetic analysis.

\begin{tabular}{lcl}
\hline Stratigraphic congruence measure & Calculated value & $\mathrm{p}$ value \\
\hline Stratigraphic consistency index & 0.5 & 0.05 \\
Relative completeness index & 29.842 & $3.2 \times 10^{-5}$ \\
Gap excess ratio & 0.676 & $2.5 \times 10^{-5}$ \\
Manhattan stratigraphic measure* & 0.086 & $3.4 \times 10^{-8}$ \\
\hline
\end{tabular}

synapomorphies (Fig. 2, Node D). Pycnocrinus Miller, 1883 is the first genus to diverge within the monobathrid clade, and the remainder of the tree is balanced in topology with two clades of five and six taxa, respectively. The characters supporting these clades are predominantly related to branching patterns in fixed brachials. The five-genus clade is united by the presence of the following: (1) fixed brachials that branch twice within the calyx, (2) 20 free arm openings, and (3) two secundibrachials, all of which represent synapomorphies (Fig. 2, Node E). The six-genus clade is united by the presence of: (1) fixed brachials that branch once within the calyx, (2) 10 free arm openings, and (3) three or more secundibrachials (Fig. 2, Node F).

The diplobathrid clade as recognized herein comprises 33 Ordovician taxa. Most morphological characters are variable across the clade, exhibiting a graded transition from states that are more similar to those of monobathrids and stem taxa. The only trait shared by all genera in the diplobathrid clade is the presence of an infrabasal circlet (Fig. 2, Node G). In addition to: (1) the presence of infrabasals, several characters are present in most genera with only a few exceptions, including (2) concave calyx base, (3) basals only partially visible in side view, and (4) interruption of the radial circlet in all interrays. Several distinct subclades are present within the diplobathrid clade, although most have poor correspondence to currently recognized families. One of the largest clades, which contains 12 genera, broadly corresponds to the family Anthracocrinidae, although some genera included in this group are currently classified as belonging to the Rhodocrinitidae. The characters uniting this clade are: (1) the presence of 15-20 arm openings, and (2) a maximum of two bifurcations in the fixed and free brachials, both of which are synapomorphies (Fig. 2, Node H). Other clades have little correspondence to traditional family divisions, being comprised of genera from the Rhodocrinitidae, Cleiocrinidae, and Dimerocrinitidae; Anthracocrinidae and Rhodocrinitidae; or strictly Rhodocrinitidae.

\section{Discussion}

Aims of the study.-The objective of this study was to infer the phylogeny of the Ordovician Camerata and to use the resulting 
phylogeny to identify monophyletic groups, relative branching order, and patterns of morphologic evolution in early camerate crinoids. The recovered trees provide a detailed view of early evolutionary relationships among camerate crinoids and serve as a phylogenetic framework for subsequent systematic work. The recovered phylogeny of Ordovician camerates indicates systematic revision is needed at the suprageneric level. Because this study focused on Ordovician camerates, it is best suited for assessing questions related to evolutionary relationships at the base of the camerate tree of life, such as the affinity of Reteocrinidae with Camerata and the monophyly of orders Monobathrida and Diplobathrida. For this reason, the primary emphasis is on systematic revisions at the suprageneric level. Ongoing analyses of post-Ordovician Diplobathrida and Monobathrida (Cole, 2015) are expected to further inform evolutionary relationships within these clades, and thus a comprehensive systematic revision will be postponed until more inclusive phylogenetic analyses are completed for the Camerata.

Implications for systematic revision of the Camerata.-On the basis of both the preliminary analysis presented herein and the analysis of Ausich et al. (2015), Camerata is recognized as a monophyletic group. As such, it should be maintained as a subclass and is formally defined by Wright et al. (2017). In the phylogeny of the Ordovician Camerata presented herein, the majority of taxa fall within one of two clades. These clades correspond closely to Monobathrida and Diplobathrida as historically defined, and thus, these orders should be retained based on the results of this analysis. Minor revisions, primarily reassignment of genera from each order to other groups, are required to redefine both orders as monophyletic. Formal phylogeny-based definitions are provided for Monobathrida and Diplobathrida by Wright et al. (2017). The terms 'Monobathrida' and 'Diplobathrida' will be used for the remainder of this discussion to refer only to taxa that belong to these clades, as identified based on the phylogenetic inferences presented herein. The remaining taxa that are not contained within Monobathrida and Diplobathrida occupy a basal position in the tree with respect to these two clades and are therefore identified as 'stem taxa.' Because members of the monobathrid and diplobathrid clades are more closely related to each other than to the stem taxa, it is fitting that a new term be erected to reflect evolutionary relationships between camerates and to maintain clarity in taxonomic communication. The term 'Eucamerata' is proposed to designate the clade containing all members of Monobathrida and Diplobathrida; stem taxa are excluded from this group. In Figure 2, Eucamerata is represented by Node B and all of its descendents. Formal definition of 'Eucamerata' is given by Wright et al. (2017). Consequently, the stem taxa identified herein are informally designated as stem eucamerates. The term 'stem' is here used to indicate a paraphyletic assemblage of early diverging camerate lineages with the Eucamerata as their nearest outgroup.

Taxa recognized as stem eucamerates include Eknomocrinus, Cnemecrinus, Adelphicrinus, Reteocrinus, and Quechuacrinus. Although these genera are all currently assigned to either the Monobathrida or Diplobathrida, their phylogenetic position as stem taxa indicates they should not be assigned to either of these orders. Based on the preliminary analysis, members of the Reteocrinidae are more closely related to camerates than to other crinoid groups and thus should maintain their classification as camerate taxa. Not all genera currently assigned to the Reteocrinidae form a cohesive family, however. Reteocrinus and Quechuacrinus form a clade of stem eucamerates, whereas Cnemecrinus is an independent stem lineage, and Gaurocrinus occupies a position within Eucamerata. Retention of Reteocrinus and Quechuacrinus as reteocrinids and removal of the other genera from this family would be the best approach to amend Reteocrinidae to represent a monophyletic group. The stem eucamerates form an evolutionary grade, and as such, a suite of diagnostic traits is difficult to assemble that applies to all stem eucamerates. There are several traits, however, that are commonly shared by stem eucamerates, the most notable of which include variable location of the primaxil, apinnulation, rectilinear uniserial brachials, and pentameric stems. All these traits differ between eucamerates and stem eucamerates.

As traditionally defined, most previously recognized Ordovician diplobathrid families are not supported by the tree produced in this study. The family Rhodocrinitidae, a heterogeneous group to which more than $40 \%$ of all diplobathrid genera are assigned, appears to represent a morphological grade rather than a clade. In part, this is likely because the characters used to diagnose rhodocrinitids are not unique to this family (Kolata, 1982; Ausich, 1986). One morphological character that is widely employed as a distinguishing feature of the Rhodocrinitidae is the separation of the radials in all interrays. However, several other diplobathrid families possess this character, including the Anthracocrinidae and Anthemocrinidae, both of which first appeared during the Ordovician. In this study, the largest clade within Diplobathrida comprises anthracocrinids in addition to rhodocrinitids, and most other clades include a combination of rhodocrinitid genera and genera from other families. This confirms previous suggestions that systematic revisions at the family level (Brower and Veinus, 1974; Kolata, 1982), and of the Rhodocrinitidae in particular (Ausich, 1986), are in order. It should be noted that several diplobathrid families, such as Dimerocrinitidae and Anthemocrinidae, have low generic diversity in the Ordovician, and thus their placement within this analysis should presently be treated with caution pending analyses that include a broader sample of post-Ordovician taxa. Similarly, the division of suborders Eudiplobathrina and Zygodiplobathrina and the superfamilies Rhodocrinitacea and Dimerocrinitacea requires sampling of post-Ordovician taxa to adequately test the validity of these groups.

As traditionally defined, the 14 Ordovician monobathrid genera included in this study are assigned to nine different families. Most of these families are represented by only a single Ordovician genus, and thus the present analysis does little to resolve the details of family-level classification. However, some family-level divisions are represented by closely related taxa, including Periglyptocrinus Wachsmuth and Springer, 1897 and Glyptocrinus Hall, 1847 (Glyptocrinidae); Canistrocrinus Wachsmuth and Springer, 1885 and Xenocrinus Miller, 1881 (Tanaocrinidae); and Eopatelliocrinus Brower, 1973 and Macrostylocrinus Hall, 1852 (Patelliocrinidae). Likewise, the suborder Compsocrinina is represented by only two Ordovician genera, preventing confident assessment of the division between the monobathrid suborders Compsocrinina and Glyptocrinina. Ordovician monobathrids are less diverse than diplobathrids and did not become significant 
faunal constituents until their radiation after the end-Ordovician extinction. For this reason, the present analysis primarily aimed to test the monophyly of the Diplobathrid and Monobathrida and serves only as a preliminary analysis of other relationships among suprageneric taxa (e.g., families, superfamilies). Phylogenetic analyses including post-Ordovician taxa will be more suited to assessing the monophyly of and relationships among traditionally recognized families, superfamilies, and suborders (Cole 2017).

Patterns of early camerate morphological evolution.-The inferred phylogeny of Ordovician camerates provides a framework for identifying patterns of morphological evolution within the clade. One of the most notable of these morphological characters is the monocyclic versus dicyclic condition, which has traditionally been foundational to partitioning taxa into the order Monobathrida versus the order Diplobathrida (Moore and Laudon, 1943a). Ancestral state reconstruction using the tree recovered from the preliminary analysis indicates dicycly is the plesiomorphic condition. This is consistent with the interpretation of Guensburg and Sprinkle (2003). Order of stratigraphic appearance cannot be used to establish the ancestral condition in camerates because the first appearances of monobathrids and diplobathrids are essentially the same stratigraphically. The recovered tree indicates transitions between the monocyclic/dicyclic conditions must have occurred at least twice early in the history of the Camerata, regardless of whether Eknomocrinus or Cnemecrinus is designated as the outgroup. Among Ordovician camerates, the number of circlets appears to have later become fixed once the two major camerate clades were established. This suggests the underlying developmental pathways responsible for the monocyclic versus dicyclic condition may not have been canalized early in the history of the Camerata but later became fixed. Because of the affinity of the Floian genera Celtocrinus and Proexenocrinus with Monobathrida and Diplobathrida, respectively, this trait must have been fixed within these clades by at least the Floian. Although this does not rule out later transitions between monocycly and dicycly via reversals, as is known to have occurred in other crinoid lineages (Sprinkle, 1982b; Wright, 2017), it indicates that the presence or absence of the infrabasal circlet is highly conserved in at least Middle-Late Ordovician camerates.

A similar pattern is observed in stem eucamerates with regard to the number of primibrachial plates and the plating of the interrays. Both these characters undergo transitions from variable or irregular states in stem eucamerates to more consistent, invariable states in the Eucamerata. Complex and disordered plating has been suggested to be a basal trait of crinoids (Guensburg, 2012) and is largely supported by the results of the phylogenetic analyses presented herein. In all Ordovician monobathrids and diplobathrids, two primibrachials are incorporated into the calyx, with the second primibrachial being axillary. In the stem eucamerates, however, the number of primibrachials is variable, with two in Cnemecrinus, two, three, or four in Reteocrinus, Adelphicrinus, and Eknomocrinus, and three or four in Quechuacrinus. This variability of primibrachials among genera, species, and individuals contrasts strikingly with other Ordovician camerates; the only exception is Wilsonicrinus, which has one primibrachial. Plating of the interrays follows a similar trend of irregular to regular plating across the tree. In stem taxa, interray plating is irregular in all genera except Cnemecrinus. Although irregular interray plating is not absent from Ordovician monobathrids and diplobathrids, it is an uncommon feature that is present only in restricted groups. Thus, it is possible that this character represents gradually increasing developmental constraint of interray plating during the early evolutionary history of the Camerata.

\section{Conclusions}

This study used a parsimony analysis to infer the phylogeny of the Ordovician Camerata. A preliminary analysis supported classification of Reteocrinidae as a camerate family and identified the Tremadocian camerate genera Cnemecrinus and Eknomocrinus as sister to the rest of the Camerata. A more comprehensive analysis inferred a phylogeny that serves as a framework for assessing the monophyly of higher taxa and identifying patterns of morphologic evolution within the clade. Based on the topology of the recovered tree, the traditional orders Monobathrida and Diplobathrida are supported, although minor revisions are required for them to represent monophyletic groups. Several genera are stem taxa that occupy a basal position in the tree; the monobathrid and diplobathrid clades are more closely related to each other than to these basal genera. The term 'Eucamerata' is proposed to represent the monobathriddiplobathrid clade, and the stem taxa are subsequently designated 'stem eucamerates.' Preliminary conclusions can be made regarding suprageneric classification within the orders Monobathrida and Diplobathrida, such as the polyphyletic nature of the family Rhodocrinitidae, and regarding patterns of morphologic evolution, such as transitions between the monocyclic and dicyclic conditions.

Understanding the phylogenetic relationships of crinoids is of particular importance during the Ordovician because this time interval represents their earliest known diversification. Although camerates are a major lineage that diverged from other crinoids early in their evolutionary history, the evolutionary relationships and phylogenetic validity of suprageneric ranks have long remained untested. As the first quantitative analysis to infer the phylogeny of all well-preserved Ordovician camerate genera, this study contributes to our understanding of the crinoid tree of life and is the first step toward a comprehensive phylogenetic classification of camerate crinoids. In addition to establishing the monophyly of higher taxa within the Camerata, informing systematic revision of Ordovician camerates, and elucidating early patterns of morphological evolution within the clade, this phylogeny provides a framework for future studies of camerate diversity, disparity, morphology, and paleoecology within an evolutionary context.

\section{Acknowledgments}

I thank K. Hollis (National Museum of Natural History), T. Ewin (Natural History Museum, London), P. Mayer (Field Museum), and K. Riddington (Lapworth Museum) for access to 
and assistance with specimens in museum collections; S. Sheffield for assistance coding Eumorphocystis; and S. Edie for kindly providing lodging while I visited the Field Museum collections. This study and an early draft of the manuscript were greatly improved by innumerable discussions with W. Ausich and D. Wright. I thank T. Kammer and an anonymous reviewer for thoughtful reviews of the manuscript and S. Zamora for helpful comments. This research was supported in part by graduate research grants from the Paleontological Society, Sigma Xi, The Ohio State University Friends of Orton Hall fund, and the Palaeontological Association, in addition to the National Science Foundation Assembling the Echinoderm Tree of Life grant (W. Ausich, DEB 1036416).

\section{Accessibility of supplemental data}

Data available from the Dryad Digital Repository: https://doi. org/10.5061/dryad.js3ph.

\section{References}

Ausich, W.I., 1985, New crinoids and revision of the superfamily Glyptocrinacea (early Silurian, Ohio): Journal of Paleontology, v. 59, p. 793-808.

Ausich, W.I., 1986, Early Silurian rhodocrinitacean crinoids (Brassfield Formation, Ohio): Journal of Paleontology, v. 60, p. 84-106.

Ausich, W.I., 1996, Crinoid plate circlet homologies: Journal of Paleontology, v. 70 , p. $955-964$.

Ausich, W.I., 1998a, Early phylogeny and subclass division of the Crinoidea (Phylum Echinodermata): Journal of Paleontology, v. 72, p. 499-510.

Ausich, W.I., 1998b, Phylogeny of Arenig to Caradoc crinoids (Phylum Echinodermata) and suprageneric classification of the Crinoidea: The University of Kansas Paleontological Contributions, v. 9, p. 1-36.

Ausich, W.I., and Copper, P., 2010, The Crinoidea of Anticosti Island, Québec (Late Ordovician to early Silurian): Palaeontographica Canadiana, v. no. 29,157 p.

Ausich, W.I., and Deline, B., 2012, Macroevolutionary transition in crinoids following the Late Ordovician extinction event (Ordovician to early Silurian): Palaeogeography, Palaeoclimatology, Palaeoecology, v. 361 , p. 38-48.

Ausich, W.I., Kammer, T.W., and Baumiller, T.K., 1994, Demise of the middle Paleozoic crinoid fauna: A single extinction event or rapid faunal turnover?: Paleobiology, v. 20, p. 345-361.

Ausich, W.I., Bolton, T.E., and Cummings, L.M., 1998, Whiterockian (Ordovician) crinoid fauna from the Table Head Group, western Newfoundland, Canada: Canadian Journal of Earth Science, v. 35, p. 121-130.

Ausich, W.I., Gil Cid, M.D., and Alonso, P.D., 2002, Ordovician [Dobrotivian (Llandeillian Stage) to Ashgill] crinoids (Phylum Echinodermata) from the Montes de Toledo and Sierra Morena, Spain with implications for paleogeography of peri-Gondwana: Journal of Paleontology, v. 76, p. 975-992.

Ausich, W.I., Sá, A.A., and Gutiérrez-Marco, J., 2007, New and revised occurrences of Ordovician crinoids from southwestern Europe: Journal of Paleontology, v. 81, p. 1374-1383.

Ausich, W.I., Kammer, T.W., Rhenberg, E.C., and Wright, D.F., 2015, Early phylogeny of crinoids within the pelmatozoan clade: Palaeontology, v. 58, p. 937-952.

Bapst, D.W., and Hopkins, M.J., 2016, Comparing cal3 and other a posterior time-scaling approaches in a case study with the Pterocephaliid trilobites: Paleobiology, v. 43, p. 49-67.

Bassler, R.S., 1943, New Ordovician cystidean echinoderms from Olkahoma: American Journal of Science, v. 241, p. 694-703.

Bell, M.A., and Lloyd, G.T., 2015, strap: An R package for plotting phylogenies against stratigraphy and assessing their stratigraphic congruence: Palaeontology, v. 58 , p. 379-389.

Benton, M.J., and Storrs, G.W., 1994, Testing the quality of the fossil record: Paleontological knowledge is improving: Geology, v. 22, p. 111-114.

Billings, E., 1857, New species of fossils from Silurian rocks of Canada: Canada Geological Survey, Report of Progress 1853-1856, Report for the year, v. 1856, p. $247-345$.

Billings, E., 1859, On the Crinoideae of the lower Silurian rocks of Canada: Canadian Geological Survey, Figures and Descriptions of Canadian Organic Remains, Decade, v. 4, p. 7-66.
Bockelie, J.F., 1981, Functional morphology and evolution of the cystoid Echinosphaerites: Lethaia, v. 14, p. 189-202.

Bockelie, J.F., 1984, The Diploporita of the Oslo region, Norway: Palaeontology, v. 27, p. 1-68.

Botting, J.P., 2003, Llanvirn (Middle Ordovician) echinoderms from Llandegley Rocks, central Wales: Palaeontology, v. 46, p. 685-708.

Branson, E.B., and Peck, R.E., 1940, A new cystoid from the Ordovician of Oklahoma: Journal of Paleontology, v. 14, p. 89-92.

Brower, J.C., 1973, Crinoids from the Girardeau Limestone (Ordovician): Palaeontographica Americana, v. 7, p. 263-499.

Brower, J.C., 1974, Upper Ordovician xenocrinids (Crinoidea, Camerata) from Scotland: The University of Kansas Paleontological Contributions, v. Paper 67 , p. $1-25$

Brower, J.C., 1994, Camerate crinoids from the Middle Ordovician (Galena Group, Dunleith Formation) of northern Iowa and southern Minnesota: Journal of Paleontology, v. 68, p. 570-599.

Brower, J.C., and Veinus, J., 1974, Middle Ordovician crinoids from southwestern Virginia and eastern Tennessee: Bulletins of American Paleontology, v. 66, p. 1-125.

Carlson, S.J., 2001, Ghosts of the past, present, and future in brachiopod systematics: Journal of Paleontology, v. 75, p. 1109-1118.

Cole, S.R., 2015, A phylogenetic test of the suprageneric classification of diplobathrid crinoids: Geological Society of America Abstracts with Programs, v. 47, p. 853.

Cole, S.R., and Ausich, W.I., 2015, Phylogenetic analysis of the Ordovician Diplobathrida (Subclass Camerata, Class Crinoidea): Implications for early camerate evolution, in Zamora, S., and Rábano, I., eds., Progress in Echinoderm Paleobiology: Cuadernos del museo Geominero, 19, Instituto Geológico y Minero de España, p. 41-44.

Cole, S.R., Ausich, W.I., Colmenar, J., and Zamora, S., 2017, Filling the Gondwanan gap: Diverse crinoids from the Castillejo and Fombuena formations (Middle and Upper Ordovician, Iberian Chains, Spain): Journal of Paleontology, doi: 10.1017/jpa.2016.135.

Donovan, S.K., and Cope, J.C.W., 1989, A new camerate crinoid from the Arenig of South Wales: Palaeontology, v. 32, p. 101-107.

Donovan, S.K., and Gilmour, N., 2003, New camerate crinoids from the Ordovician of Scotland and Wales: Transactions of the Royal Society of Edinburgh: Earth Sciences, v. 93, p. 155-161.

Eckert, J.D., 1988, Late Ordovician extinction of North American and British crinoids: Lethaia, v. 21, p. 147-167.

Farris, J.S., 1989, The retention index and rescaled consistency index: Cladistics, v. 5 , p. $417-419$.

Foote, M., 1994, Morphological disparity in Ordovician-Devonian crinoids and the early saturation of morphological space: Paleobiology, v. 20, p. $320-344$.

Foote, M., 1997, Estimating taxonomic durations and preservation probability: Paleobiology, v. 23, p. 278-300.

Foote, M., 1999, Morphological diversity in the evolutionary radiation of Paleozoic and post-Paleozoic crinoids: Paleobiology, v. 25, p. 1-115.

Foote, M., and Raup, D.M., 1996, Fossil preservation and the stratigraphic ranges of taxa: Paleobiology, v. 22, p. 121-140.

Frest, T.J., and Strimple, H.L., 1981, New camerate crinoids from the Silurian of North America: Journal of Paleontology, v. 55, p. 639-655.

Frest, T.J., Strimple, H.L., and Kelly, S.M., 1976, A new Ordovician camerate crinoid from Kentucky: Southeastern Geology, v. 17, p. 139-148.

Gil, D., Domínguez, P., Torres, M., and Jiménez, I., 1999, A mathematical tool to analyze radially symmetrical organisms and its application to a new camerate from Upper Ordovician of south western Spain: Geobios, v. 32, p. 861-867.

Guensburg, T.E., 1984, Echinodermata of the Middle Ordovician Lebanon Limestone, central Tennessee: Bulletins of American Paleontology, v. $86,100 \mathrm{p}$.

Guensburg, T.E., 2012, Phylogenetic implications of the oldest crinoids: Journal of Paleontology, v. 86, p. 455-461.

Guensburg, T.E., and Sprinkle, J., 2003, The oldest known crinoids (Early Ordovician, Utah) and a new crinoid plate homology system: Bulletins of American Paleontology, v. 364, 43 p.

Guensburg, T.E., and Sprinkle, J., 2009, Solving the mystery of crinoid ancestry: New fossil evidence of arm origin and development: Journal of Paleontology, v. 83 , p. $350-364$.

Guensburg, T.E., and Waisfeld, B.G., 2015, South America's earliest (Ordovician, Floian) crinoids: Journal of Paleontology, v. 89, p. 622-630.

Gyllenhaal, J.A., 1772, Beskrifning pa de sa kallade Crystall-aplen och kalkbollar, sasom petreficerade Djur af Echini genus, eller dess narmaste slagtningar: Kongl. Svenska Vetenskaps Academiens Handlingar, v. 33, p. 239-261.

Hall, J., 1847, Palaeontology of New York, Volume I. Containing Descriptions of the Organic Remains of the Lower Division of the New-York System (Equivalent of the Lower Silurian Rocks of Europe), Natural History of New York, Part 6: Albany, New York, C. Van Benthuysen, 338 p. 
Hall, J., 1852, Palaeontology of New York, Volume 2. Containing Descriptions of the Organic Remains of the Lower Middle Division of the New-York System, Natural History of New York, Part 6: New York, D. Appleton \& Co. and Wiley \& Putnam; Boston, Gould, Kendall, \& Lincoln, 362 p.

Hall, J., 1866, Descriptions of new species of Crinoidea and other fossils from the lower Silurian strata of the age of the Hudson-River Group and Trenton Limestone: Albany, 17 p. (privately distributed preprint).

Haugh, B.N., 1979, Late Ordovician channel-dwelling crinoids from southern Ontario, Canada: American Museum Novitates, v. 2665, p. 1-25.

Hudson, G.H., 1907, On some Pelmatozoa from the Chazy Limestone of New York: New York State Museum Bulletin Geology Papers, v. 107, p. $97-127$.

Huelsenbeck, J.P., 1994, Comparing the stratigraphic record to estimates of phylogeny: Paleobiology, v. 20, p. 470-483.

Jobson, L., and Paul, C.R.C., 1979, Compagicrinus fenestratus, a new Lower Ordovician inadunate crinoid from North Greenland: Rapport, Grønlands Geologiske Undersogelse, v. 91, p. 1-81.

Kammer, T.W., Sumrall, C.D., Zamora, S., Ausich, W.I., and Deline, B., 2013, Oral region homologies in Paleozoic crinoids and other plesiomorphic pentaradial echinoderms: PLoS ONE, v. 8, 16 p. doi: 10.1371/journal. pone.0077989.

Kelley, P.H., Fastovsky, D.E., Wilson, M.A., Laws, R.A., and Raymond, A., 2013, From paleontology to paleobiology: A half-century of progress in understanding life history: Geological Society of America Special Papers, v. 500 , p. $191-232$.

Kelly, S.M., 1986, Classification and evolution of Class Crinoidea: Abstracts of the Fourth North American Paleontological Convention, A23.

Kelly, S.M., Frest, T.J., and Strimple, H.L., 1978, Additional information on Simplococrinus persculptus: Journal of Paleontology, v. 52, p. 1227-1232.

Kolata, D.R., 1975, Middle Ordovician echinoderms from northern Illinois and southern Wisconsin: Journal of Paleontology, Memoir 7, v. 49, 74 p.

Kolata, D.R., 1982, Camerates, in Sprinkle, J., ed., Echinoderm faunas from the Bromide Formation (Middle Ordovician) of Oklahoma: The University of Kansas Paleontological Contributions, Monograph, v. 1, p. 170-205.

Le Menn, J., and Spjeldnaes, N., 1996, Un nouveau crinoïde Dimerocrinitidae (Camerata, Diplobathrida) de l'Ordovicien supérieur du Maroc: Rosfacrinus robustus nov. gen., nov. sp.: Geobios, v. 29, p. 341-351.

Maddison, W.P., and Maddison, D.R., 2015, Mesquite: A modular system for evolutionary analysis, Version 3.04. http://mesquiteproject.org.

M'Coy, F., 1850, On some new genera and species of Silurian Radiata in the collection of the University of Cambridge: Annals and Magazine of Natural History, v. 6, p. 270, 289-290.

Meek, F.B., 1872, Descriptions of new western Palaeozoic fossils mainly from the Cincinnati Group of the lower Silurian series of Ohio: Proceedings of the Academy of Natural Sciences of Philadelphia, v. 23, p. 308-337.

Miller, S.A., 1881, Description of some new and remarkable crinoids and some other fossils of the Hudson River Group and notice of Strotocrinus bloomfieldensis: Journal of the Cincinnati Society of Natural History, v. 4, p. 69-77.

Miller, S.A., 1883, Glyptocrinus redefined and restricted, Gaurocrinus, Pycnocrinus and Compsocrinus established, and two new species described: Journal of the Cincinnati Society of Natural History, v. 6, p. $217-234$.

Miller, S.A., and Gurley, W.F.E., 1894, New genera and species of Echinodermata: Illinois State Museum, Bulletin, v. 5, p. 1-53.

Moore, R.C., 1952, Evolution rates among crinoids: Journal of Paleontology, v. 26, p. $338-352$.

Moore, R.C., and Laudon, L.R., 1943a, Evolution and classification of Paleozoic crinoids: Geological Society of America Special Paper, v. 46, p. 1-154.

Moore, R.C., and Laudon, L.R., 1943b, Trichinocrinus, a new camerate crinoid from Lower Ordovician (Canadian?) rocks of Newfoundland: American Journal of Science, v. 241, p. 262-268.

O’Malley, C.E., Ausich, W.I., and Chin, Y., 2016, Deep echinoderm phylogeny preserved in organic molecules from Paleozoic fossils: Geology, v. 44, p. 379-382.

Pol, D., and Norell, M.A., 2001, Comments on the Manhattan stratigraphic measure: Cladistics, v. 17, p. 285-289.

Ramsbottom, W.H.C., 1961, A monograph on British Ordovician Crinoidea: Palaeontographical Society, v. 114, p. 1-37.

Rhenberg, E.C., Ausich, W.I., and Kammer, T.W., 2015, Generic concepts in the Actinocrinitidae Austin and Austin, 1842 (class Crinoidea) and evaluation of generic assignments of species: Journal of Paleontology, v. 89, p. 1-19.

Rozhnov, S.V., 1988, Morphology and systematic position of Lower Ordovician crinoids: Paleontologicheskii Zhurnal, v. 2, p. 67-79. [in Russian].

Shavit, L., Penny, D., Hendy, M.D., and Holland, B.R., 2007, The problem of rooting rapid radiations: Molecular Biology and Evolution, v. 24, p. $2400-2411$.

Siddall, M.E., 1998, Stratigraphic fit to phylogenetics: A proposed solution: Cladistics, v. 14, p. 201-208.
Simms, M.J, 1993, Reinterpretation of thecal plate homology and phylogeny in the Class Crinoidea: Lethaia, v. 26, p. 303-312.

Slocom, A.W., 1924, Part one, in Slocom, A.W., and Foerste, A.F., eds., New echinoderms from the Maquoketa beds of Fayette County, Iowa: Iowa Geological Survey, v. 29, p. 320-344.

Smith, A.B., 1994a, Rooting molecular trees: Problems and strategies: Biological Journal of the Linnaean Society, v. 51, p. 279-292.

Smith, A.B., 1994b, Systematics and the Fossil Record: Documenting Evolutionary Patterns: Oxford, Blackwell Scientific Publications, 223 p.

Smith, A.B., and Zamora, S., 2009, Rooting phylogenies of problematic fossil taxa; a case study using cinctans (stem-group echinoderms): Palaeontology, v. 52 , p. $803-821$.

Smith, A.B., Lafay, B., and Christen, R., 1992, Comparative variation of morphological and molecular evolution through geologic time: $28 \mathrm{~S}$ ribosomal RNA versus morphology in echinoids: Philosophical Transactions: Biological Sciences, v. 338, p. 365-382.

Springer, F., 1905, Cleiocrinus: Harvard College Museum of Comparative Zoology Memoir, v. 25, p. 91-114.

Springer, F., 1911, On a Trenton echinoderm fauna at Kirkfield, Ontario: Canada Department Mines, Memoir, v. 15-P, p. 1-70.

Sprinkle, J., 1982a, Cylindrical and globular rhombiferans, in Sprinkle, J., ed., Echinoderm faunas from the Bromide Formation (Middle Ordovician) of Oklahoma: The University of Kansas Paleontological Contributions, Monograph, v. 1, p. 231-273.

Sprinkle, J., 1982b, Hybocrinus, in Sprinkle, J., ed., Echinoderm faunas from the Bromide Formation (Middle Ordovician) of Oklahoma: The University of Kansas Paleontological Contributions, Monograph, v. 1, p. 119-128.

Sprinkle, J., and Wahlman, G.P., 1994, New echinoderms from the Early Ordovician of west Texas: Journal of Paleontology, v. 68, p. 324-338.

Strimple, H.L., and McGinnis, M.R., 1972, A new camerate crinoid from the Al Rose Formation, Lower Ordovician of California: Journal of Paleontology, v. 46, p. $72-74$.

Strimple, H.L., and Watkins, W.T., 1955, New Ordovician echinoderms: Journal of the Washington Academy of Science, v. 45, p. 347-353.

Sumrall, C.D., 2014, Echinoderm phylogeny-The path forward: Geological Society of America Abstracts with Programs, v. 46, p. 78.

Sumrall, C.D., 2015, Understanding the oral area of derived stemmed echinoderms, in Zamora, S., and Rábano, I., eds., Progress in Echinoderm Paleobiology: Cuadernos del museo Geominero, 19, Instituto Geológico y Minero de España, p. 169-173.

Sumrall, C.D., and Schumacher, G.A., 2002, Cheirocystis fultonensis, a new glyptocystitidoid rhombiferan from the Upper Ordovician of the Cincinnati Arch-Comments on cheirocrinid ontogeny: Journal of Paleontology, v. 76, p. $843-851$.

Swofford, D.L., 2003, PAUP* Version 4.0.b10 Phylogenetic Analysis Using Parsimony and Other Methods: Sunderland, MA, Sinauer Associates.

Ubaghs, G., 1953, Classe des Crinoides, in Piveteau, J., ed., Traité de Paléontologie: Paris, Maison et Cie, v. 3, p. 658-773.

Ubaghs, G., 1963, Rhopalocystis destombesi n. g., n. sp. Eocrinoide de l'Ordovicien inferieur (Tremadocien superieur) du Sud marocain: Notes du service geologic du Maroc, v. 23, p. 25-44.

Ubaghs, G., 1969, Aethocrinus moorei Ubaghs, n. gen, n. sp., le plus ancien Crinoïde dicyclique connu: University of Kansas Paleontological Contributions, v. 38 , p. $1-25$.

Ubaghs, G., 1978, Camerata, in Moore, R.C., and Teichert, C., eds., Treatise on Invertebrate Paleontology. Pt. T. Echinodermata 2: Lawrence, Geological Society of America and University of Kansas Press, p. T409-T519.

Wachsmuth, C., and Springer, F., 1880-1886, Revision of the Palaeocrinoidea. Proceedings of the Academy of Natural Sciences of Philadelphia Pt. II. Family sphaeroidocrinidae, with the sub-families Platycrinidae, Rhodocrinidae, and Actinocrinidae (1881), p. 177-411 (separate repaged, p. 1-237). Pt. III, Sec. 1. Discussion of the classification and relations of the brachiate crinoids, and conclusions of the generic descriptions (1885), p. 225-364 (separate repaged, 1-138).

Wachsmuth, C., and Springer, F., 1897, The North American Crinoidea Camerata: Harvard College Museum of Comparative Zoology, Memoirs, v. 20 and 21,897 p.

Walcott, C.D., 1883, Descriptions of new species of fossils from the Trenton Group of New York: New York State Museum of Natural History, Annual Report, v. 35, p. 207-214.

Webster, G.D., 2003, Bibliography and index of Paleozoic crinoids, coronates, and himistreptocrinoids: Geological Society of America Special Paper 363.

Webster, G.D., and Maples, C.G., 2006, Cladid crinoid (Echinodermata) anal conditions: A terminology problem and a proposed solution: Palaeontology, v. 49 , p. $187-212$.

Weller, S., 1916, Atactocrinus, a new crinoid genus from the Richmond of Illinois: Contributions of the Walker Museum of the University of Chicago, v. 1 , p. 239-241. 
Wheeler, W.C., 1990, Nucleic acid sequence phylogeny and random outgroups: Cladistics, v. 6, p. 363-368.

Willis, M.A., 1999, Congruence between phylogeny and stratigraphy: Randomization tests and the gap excess ratio: Systematic Biology, v. 48, p. 419-580.

Wright, D.F., 2015, Fossils, homology, and "Phylogenetic Paleo-ontogeny": A reassessment of primary posterior plate homologies among fossil and living crinoids with insight from developmental biology: Paleobiology, v. 41 , p. $570-591$.
Wright, D.F., 2017, Bayesian estimation of fossil phylogenies and the evolution of early to middle Paleozoic crinoids (Echinodermata): Journal of Paleontology, doi: 10.1017/jpa.2016.141.

Wright, D.F., Ausich, W.I., Cole, S.R., Rhenberg, E.C., and Peter, M.E., 2017, Phylogenetic taxonomy and classification of the Crinoidea (Echinodermata): Journal of Paleontology, doi: 10.1017/jpa.2016.142.

Accepted 23 August 2016 